\title{
RED DATA BOOK INVERTEBRATES IN A PROTECTED AREA OF EUROPEAN RUSSIA
}

\author{
Alexander B. Ruchin ${ }^{1}$ and Anatoliy A. Khapugin ${ }^{1,2}$ \\ ${ }^{1}$ Joint Directorate of the Mordovia State Nature Reserve and National Park "Smolny" \\ Krasnaya Street, 30, Saransk, Republic of Mordovia, 430005, Russia \\ E-mail: ruchin.alexander@gmail.com; https://orcid.org/0000-0003-2653-3879 \\ ${ }^{2}$ Tyumen State University, Volodarskogo Street, 6, Tyumen, Tyumen region, 625003, Russia \\ E-mail: hapugin88@yandex.ru; https://orcid.org/0000-0002-6059-2779
}

Protected Areas are considered as primary efforts for biodiversity conservation worldwide. However, there is a lack of data on the biodiversity and threats for most of the federal-level Russian Protected Areas, especially for invertebrates. Intensive research on invertebrate diversity in Protected Areas is highly important to obtain comprehensive knowledge for the management of natural refugia of biodiversity. In the present paper, we studied the most vulnerable component of invertebrate diversity, i.e. the Red Data Book species, in the Mordovia State Nature Reserve (European Russia). We used both new (2007-2018) and literature (1936-2006) data to obtain information on habitat preferences, year of the first record, and spatial distribution in the Protected Area for 121 invertebrate Red Data Book species known from the Mordovia State Nature Reserve. Our study demonstrated a remarkable increase in the Red Data Book invertebrate diversity as a consequence of the research intensification in the Protected Area in the last ten years. This is also related to the fact that only $1-2$ records are known for a large number of species (57.9\%) within the Protected Area. The highest species richness was found close to the research stations (cordons). On one hand, this highlights their significance for biodiversity research. On the other hand, it outlines the need for performing more research in less-studied areas of the Mordovia State Nature Reserve. Finally, the species currently known for Mordovia and Russia only from this Protected Area (27 and four species, respectively) highlight the importance of the Mordovia State Nature Reserve at regional and national levels.

Key words: biodiversity, habitat preference, Mordovia State Nature Reserve, nature conservation, representativeness index

\section{INTRODUCTION}

Human impacts on nature have led to an accelerated biodiversity loss, with harmful consequences to many ecosystem processes and functions (THUILler 2007, Butchart et al. 2010, Dirzo et al. 2014). This has lead to an increase in the number of studies on biodiversity as well as in the efforts for its conservation. A consequence of these efforts is the declaration of Protected Areas in many regions of the world (HALffter 2005, Zografou et al. 2014). These areas spearhead the global conservation effort (WATson et al. 2014). Currently, the global Protected Area Network covers about 15\% of the world's terrestrial land surface (Belle et al. 2018). However, the designation of these protected 
areas rarely considers invertebrates. For the vast majority of protected areas, only studies focusing on conspicuous groups of vertebrates and plants are available (Carignan \& Villard 2002, Rodrigues et al. 2004, Young et al. 2014). The invertebrate biodiversity in Protected Areas remains largely unexplored, although these animals are key elements in the functioning of all terrestrial ecosystems. Samways (2005) and Cardoso et al. (2011) indicated that insects are almost four-fifths of the total of terrestrial species. However, estimations of the invertebrate diversity (e.g., Ramos et al. 2001) are rare due to the limited taxonomic and distribution knowledge about different taxonomic groups (MARTin-López et al. 2007). This causes a need to investigate the effectiveness of Protected Area Networks to protect the invertebrate diversity in different regions of the world. It especially concerns biodiversity coldspots (i.e., areas with low diversity, such as the Russian Federation) of the world because the main attention of researchers is often riveted on hotspots (KAREIVA \& MARVIER 2003).

Red Lists play an important role in generating public and policy support for species conservation (Rodrigues et al. 2006). Listing species according to their relative risk of extinction and comparing regularly updated Red Lists is a powerful tool in assessing the efficacy of species conservation policies (StORK et al. 1996, MACE et al. 2008). In the case of insects, and invertebrates in general, however, it has been noted that Red Lists principally reflect the state of knowledge rather than the actual status of a species' extinction risk (CARdoso et al. 2012).

In this study, we aimed to assess the current state of the Red Data Book insect diversity in a Protected Area in European Russia (Republic of Mordovia), the Mordovia State Nature Reserve. The Mordovia State Nature Reserve was established as a Protected Area in 1936. In this Protected Area, there was a lack of systematic investigations of the invertebrate diversity before 2007. During 2007-2018, more than 5,000 invertebrate species have first been discovered for the Nature Reserve in the framework of an intensive investigation of the Protected Area's entomological diversity (Ruchin et al. 2013, Makarkin \& Ruchin 2014, Ruchin \& Artaev 2016, Mandelshtam \& Egorov 2017, Ruchin \& Makarkin 2017, Ruchin \& Mikhailenko 2018). Of these, 2,600 invertebrate species were firstly found for the whole Republic of Mordovia (Makarkin \& Ruchin 2010, Bezina 2014, Bolshakov et al. 2014, Budaeva \& Ruchin 2014, Semenov 2016, Ruchin \& Egorov 2017b, Bolshakov et al. 2018, Chursina \& Ruchin 2018a), including five species newly found for the Russian Federation (Moкrousov et al. 2013, Tomaszewska et al. 2018, ZemoglyADCHUK et al. 2019). Results of the intensive entomological studies allowed a significant extension of the geographical ranges of some invertebrate species (Legalov et al. 2014, Ruchin \& Artaev 2016, Anufriev 2017, Bolshakov et al. 
2017, Egorov \& Shapovalov 2017, Ruchin \& Egorov 2018b,d,e). Concerning the Red Data Book invertebrate species, after the publication of the Red Data Book of the Republic of Mordovia (Astradamov 2005), 164 invertebrate species were recommended to be included in its second edition (MAKARKIN \& Ruchin 2015, Mikhailenko \& Ruchin 2015, Ruchin \& Egorov 2015, 2017b, Ruchin \& Nikolaeva 2015, Stoyko \& Komarova 2015, Bolshakov \& Ruchin 2016), while 35 invertebrate species were suggested to be excluded from the main list of the Red Data Book of the Republic of Mordovia (Egorov \& Ruchin 2009, Ruchin \& Nikolaeva 2015, Bolshakov \& Ruchin 2016, Ruchin \& EgoROv 2017b). The first stages of systematic conservation planning should always include data collection on the location of threatened and regionally rare species in a region or its part (Margules \& Pressey 2000).

The aim of this study was to analyse the current state of the diversity of the Red Data Book invertebrates of the Mordovia State Nature Reserve on the eve of the forthcoming second edition of the Red Data Book of the Republic of Mordovia.

\section{MATERIAL AND METHODS}

\section{Study area}

The Mordovia State Nature Reserve is situated in the northwest part of the Republic of Mordovia, Russian Federation (54.42-54.56 N, 43.04-43.36 E; up to 190 m a.s.l., Fig. 1). The Mordovia Reserve area is $321.62 \mathrm{~km}^{2}$. Its flora includes 809 species from 99 families (VARGOT et al. 2016).

Forest communities cover $89.3 \%$ of the total Mordovia Reserve area. Pine (Pinus sylvestris L.) is the main forest-forming wood species in the reserve. It forms pure or mixed forest communities. Birch (Betula pendula Roth) ranks second in areas covered by forests. It forms predominantly secondary communities at logging sites and at burned forest sites. Small-leaved linden (Tilia cordata Mill.) forests are present in the northern part of the Mordovia Reserve. Oak (Quercus robur L.) forests are distributed in the floodplain of the river Moksha in the western part of the Mordovia Reserve. Spruce (Picea abies L.) forests are located predominantly in floodplains of rivers and streams (Pushta, Vyaz-Pushta, Vorsklyay, Arga, etc.) and cover small areas. There are numerous oligotrophic mires dominated by Sphagnum or Sphagnum - Carex communities. Floodplain meadows are situated mainly in floodplains of the river Satis and the river Moksha in the western and northwestern parts of the Protected Area (Tereshin \& Tereshinina 2006, Vargot et al. 2016).

\section{Data collection and analysis}

As a target group, we selected invertebrate species included in the Red Data Book of the Republic of Mordovia, which are known from the Mordovia State Nature Reserve. Apart of them, our study considered also invertebrates suggested for inclusion for its second edition (see - Makarkin \& Ruchin 2015, Mikhailenko \& Ruchin 2015, Ruchin \& Ego- 
rov 2015, Ruchin \& Nikolaeva 2015, Bolshakov \& Ruchin 2016). At the same time, four species (Argyroneta aquatica (Clerck, 1757), Dolomedes fimbriatus (Clerck, 1757), Bombus lapidarius (Linnaeus, 1758), Centrotus cornutus (Linnaeus, 1758)), included in the Red Data Book of the Republic of Mordovia (Astradamov 2005), were excluded from our analysis because actually these invertebrates are common species in the region (personal data). 2007-2018 data on species diversity were collected predominantly by the first author. Previous data have been extracted from publications concerning the fauna of the Mordovia State Nature Reserve (Plavilshchikov 1964, Feoktistov 2011, Ruchin 2018, Ruchin \& Grishutkin 2018). Voucher specimens collected during the study period are stored in the Collection of the Mordovia State Nature Reserve and in personal collections of the authors. Some individuals were released into nature after capture.

We estimated the increase in the number of the Red Data Book invertebrate species in the Mordovia State Nature Reserve using the first record of each species in the Protected Area, and the total number of records per each species known in the Mordovia Reserve. We assigned all known records to quarters of the Protected Area. A quarter is a square forestry unit (ca. $1 \times 1 \mathrm{~km}$ ) surrounded by clearings from south to north and from west to east. Hence, species distribution among quarters follows a grid system using $1 \mathrm{~km}^{2}$ cell size.

To reveal patterns of spatial distribution of the Red Data Book invertebrates in the Mordovia State Nature Reserve, we counted the number of the Red Data Book species per quarter. These data have been used to show the biodiversity hotspots and coldspots of Red Data Book invertebrates in the Mordovia State Nature Reserve.

We analysed species confinement to different habitats by using the following habitat calssification: forests (incl. burned coniferous forest, coniferous forest, deciduous forest, mixed forest), edges of forest (incl. edge of coniferous forest, edge of deciduous forest, edge of mixed forest), forest glades (incl. glade of coniferous forest, glade of deciduous forest, glade of mixed forest), floodplain meadows, water bodies (incl. shores), man-made habitats (i.e. roadsides, arable lands, etc.), Sphagnum mires.

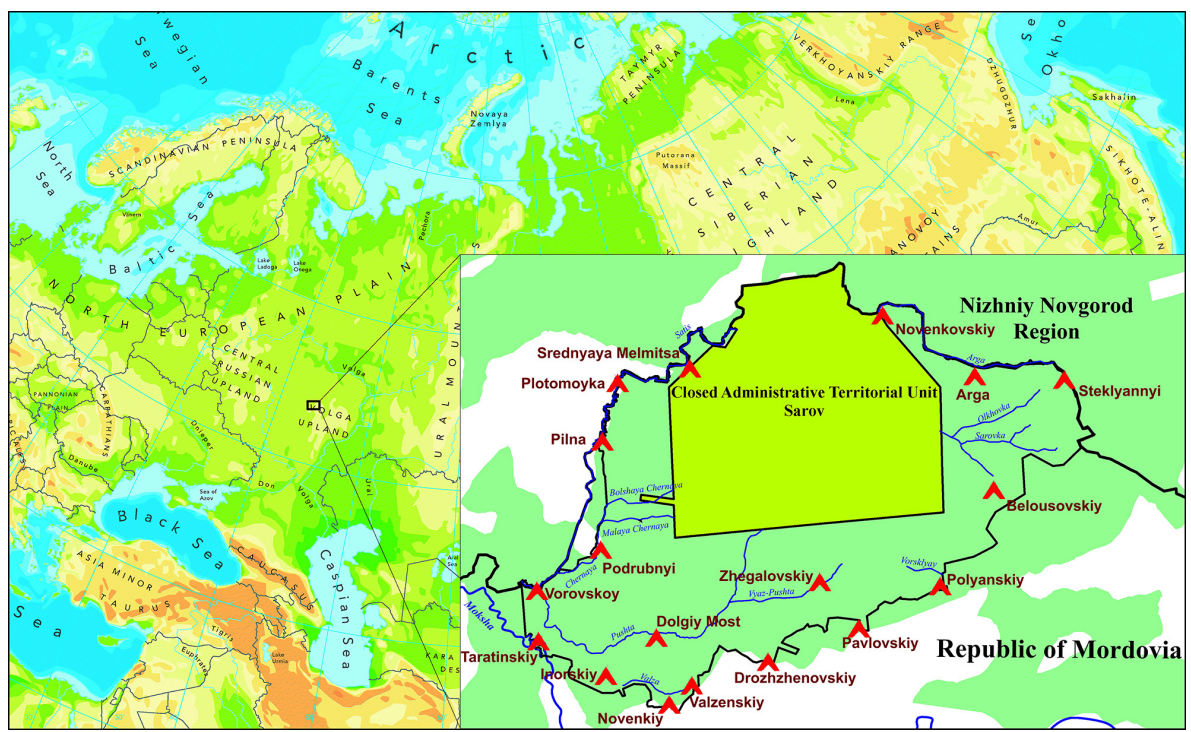

Fig. 1. Geographic location of the Mordovia State Nature Reserve in Europe. Symbols within the Mordovia State Nature Reserve indicate research stations (cordons) 
To calculate a Representativeness Index (RI) of each Red Data Book invertebrate in the Mordovia State Nature Reserve, we proposed and used the following formula:

$$
R=\frac{N_{H}}{N_{\text {TOTAL }}} \times 100 \%
$$

where $N_{\mathrm{PA}}$ is the number of taxon's locations known within a Protected Area, and $N_{\text {TOTAL }}$ is the total number of taxon's locations within a region (in this study, it is the Republic of Mordovia).

Depending on the RI values, we distinguished all Red Data Book invertebrates of the Mordovia State Nature Reserve into the following four groups using quartiles: Q1 having RI values 76-100\%, Q2 - 51-75\%, Q3 - 26-50\%, and Q4 with the RI values from $0.1 \%$ to $25 \%$.

To express the conservati on status of the invertebrate species involved in the study, we used the rarity category reported in the Red Data Book of the Republic of Mordovia (Astradamov 2005), as follows:

0 - Probably extinct species. Populations of these species have probably disappeared from the territory of the Republic of Mordovia. These species have not been recorded in the wild during the past 50 years, either in points where the species were known to be formerly present or at any other potential locations. Nevertheless, the possibility that some individuals or populations have been overlooked cannot be completely excluded.

1 - Endangered species. Species whose populations have reached critically small sizes and/or their habitats have changed in such a way that their survival is unlikely if the impact of threat factors persists.

2 - Vulnerable species. Species characterised by steadily declining populations in the region, which can quickly fall into the category of endangered species if impacts of unfavorable factors persist.

3 -Rare species. Species of high vulnerability because of their small population size in the region. They are distributed over a limited area or a large scale, but with a very low density.

4 -Indeterminate species. Species whose populations could be classified into one of the previous categories, but information about their present state is insufficient to accurately determine their status.

5 - Recovered or recovering species. Species whose abundance and distribution area (under the impact of natural factors or human actions aimed to recover species populations) lead to be recovered to a status for which they will not need special measures for protection and restoration.

Contour map has been created using the MapInfo 11.5 software.

\section{RESULTS AND DISCUSSION}

As a result of annual entomological investigations in the Mordovia State Nature Reserve and examination of available publications, we obtained data on 121 Red Data Book invertebrates known within the Protected Area (Table $1 S$ ). Among them, 12 species (10\% of the total number) are recommended to be included in the second edition of the Red Data Book of the Russian Federation (ILyAshenko et al. 2018). Notably, there are 14 such species known in the whole Republic of Mordovia. Hence, 12 of 14 (86\%) species of the Red Data Book of the Russian Federation (DANILOv-Danilyan 2001) are known to be present in the Mordovia State Nature Reserve (the two absent species are Aphodius bimaculatus (Laxmann, 1770) and Omias verruca Boheman, 1834). 
Overall, Red Data Book invertebrate species were represented by 402 locations in the Mordovia State Nature Reserve. Most of them (57.9\%) have been represented by only 1-2 records in the Mordovia State Nature Reserve (Fig. 2). The number of species per class of records followed a power function with a negative exponent. Thus most of species are known by 1 or two records, and the number of speceis known for more records decreases rapidly, with remarkably few invertebrate species represented by at least nine records (e.g., Protaetia fieberi (Kraatz, 1880) with 18 records, Xylocopa valga Gerstaecker, 1872 with 15 records, Agriades optilete (Knoch, 1781) with 13 records). This pattern is consistent with those observed for invertebrates (e.g., Pentinsaari et al. 2014, Sushro 2017) and vertebrates (Silveira et al. 2003, Pacheco \& OLmos 2005) from other contexts.

Because of the immense lack of knowledge on the conservation status of invertebrates, any intensification in the study of these animals could lead to a remarkable increase in the number of known species and their presence in Protected Areas with possible description of new taxa (ANUfRIEv 2016, Bouchard et al. 2017, MAYHEw 2018). Generalised data on the increase in the number of species known from the Mordovia State Nature Reserve between 1936 and 2018 shows that a plateu is far from being reached (Fig. 3). Thus the number of the Red Data Book invertebrates will be likely increase with further research.

The first record of a Red Data Book species (Podisma pedestris (Linnaeus, 1758)) has been reported in 1936. Plavilshchiкov (1964) published the first relatively comprehensive list of insect species for the Mordovia State Nature Reserve. In the late 1960s - early 1970s, Lepidoptera and Heteroptera were mainly investigated. Between 1936 and 1986, the list of the Red Data Book invertebrates increased up to 40 species. During the next 20 years (1986-2006), there were no additions to the list of the Red Data Book invertebrates in the Mordovia State Nature Reserve due to the complete lack of entomological

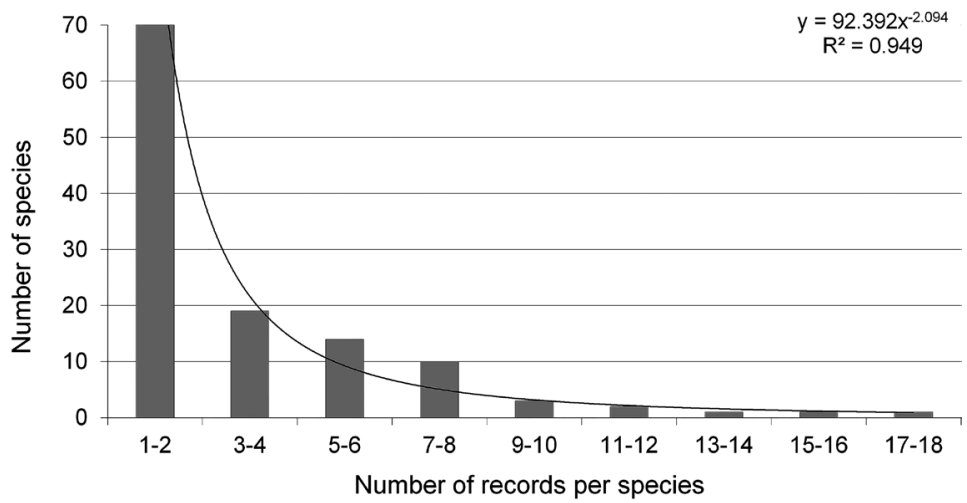

Fig. 2. Number of Red Data Book invertebrate species for different classes of records in the Mordovia State Nature Reserve 
studies. A period of intensive entomological studies in the Mordovia State Nature Reserve started in 2007. Thus, between 2007 and 2018, the fauna of the Red Data Book invertebrate species has remarkably increased (by 80 species). To obtain field data we used different approaches and catch methods: pitfall traps, light traps, fermental crown traps, Malaise traps and others (e.g., see RuchiN \& Egorov 2018a). The preparation of the first edition of the Red Data Book of the Republic of Mordovia (Astradamov 2005) was a main driving force for the study of the Red Data Book species in the region. A permanent monitoring of the Red Data Book taxa, a search for their detailed distribution, the study of their biology and ecology, and the biodiversity investigation of different invertebrate groups allowed the addition of more than 5,000 invertebrate species to the fauna of the Mordovia State Nature Reserve (Ruchin 2011, 2015a,b, 2017).

Data on the spatial distribution of the Red Data Book invertebrates in the Mordovia State Nature Reserve allowed the identification of biodiversity hotspots within the Protected Area. Figure 4 shows that the highest number of the Red Data Book invertebrate species per quarter was found in the south-west of the Mordovia State Nature Reserve. This is explained by a large diversity of landscapes and ecotones in this area. This part of the Mordovia Reserve includes floodplain meadows and deciduous forests, old-growth broad-leaved (Quercus robur, Ulmus spp., Tilia cordata) forests, oxbow lakes with shores, mixed forests with different-species in the second and third layers, large glades and edges of forests, and mires of different types. In general, the highest species diversity was observed around research stations of the Mordovia State Nature Reserve represented by the settlement of Pushta and cordons (a cordon is one or few inhabited or uninhabited building(s), which serve(s) as a home for forest rangers and/or as research stations), such as cordon Steklyannyi, cordon

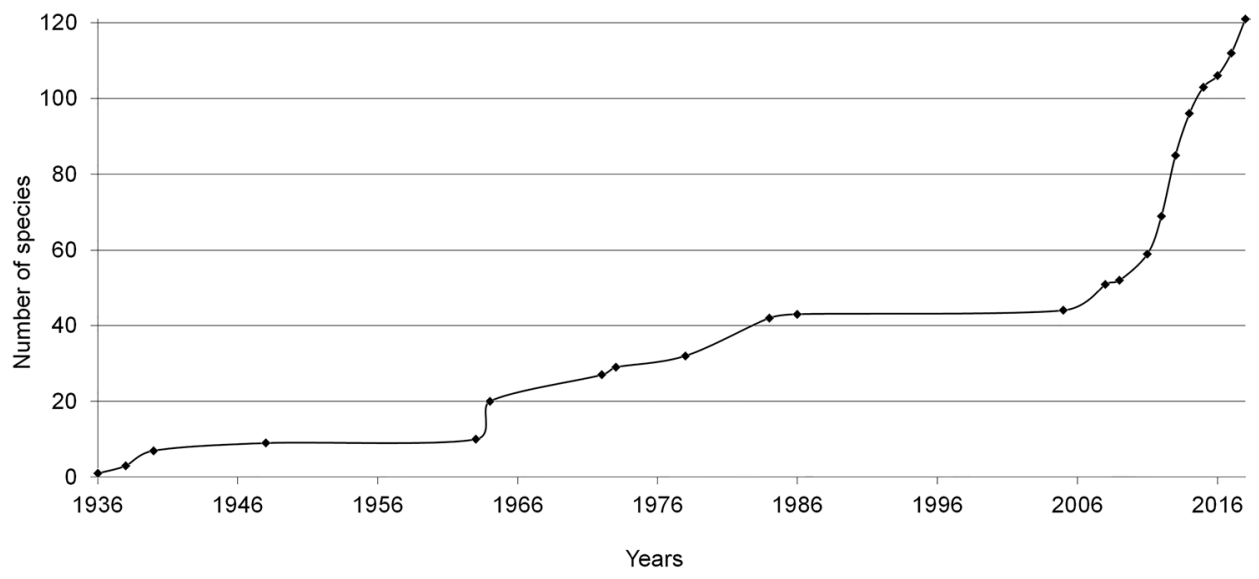

Fig. 3. Increase in the Red Data Book invertebrate species for the fauna of the Mordovia State Nature Reserve for the period 1936-2018 
Srednyaya Melnitsa, cordon Pavlovskiy, cordon Vorovskoy, cordon Inorskiy, cordon Dolgiy Most, cordon Zhegalovskiy, cordon Drozhdenovskiy - see Fig. 1). Thus, it can be seen from Fig. 4 that the presence and density of research stations (settlements and cordons) positively influences the diversity and richness of known species in the various sectors of the Protected Area. The efficiency of studies can also be increased with increasing density of research stations in other environmental studies (e.g., Mishra 2013).

Low diversity of Red Data Book invertebrate species in the central and eastern parts of the Mordovia State Nature Reserve could be explained by different reasons. First, these areas are represented predominantly by pine forests with the insignificant presence of Tilia cordata, Picea abies or Betula pendula into the second layer and with shrub layer represented mainly by Sorbus aucuparia and Frangula alnus. Thus, the lack of broad-leaved trees possibly influences negatively the diversity of saproxylic beetles. Absence of meadows affects negatively Orthoptera and Lepidoptera. In addition, the lack of water bodies negatively influences Odonata, Lepidoptera, and Mollusca. Second, the central and eastern parts of the Mordovia State Nature Reserve have been damaged by humans, as also indicated by palaeobotanical data (see NovenKo et al. 2017). In these parts of the Protected Areas, broad-leaved forests have been changed into pine forests, wildfires became more frequent and Picea abies started penetrating into the forest communities.

Analysis of habitat confinement of the Red Data Book invertebrates showed the importance of forest ecosystems as refugia for threatened species
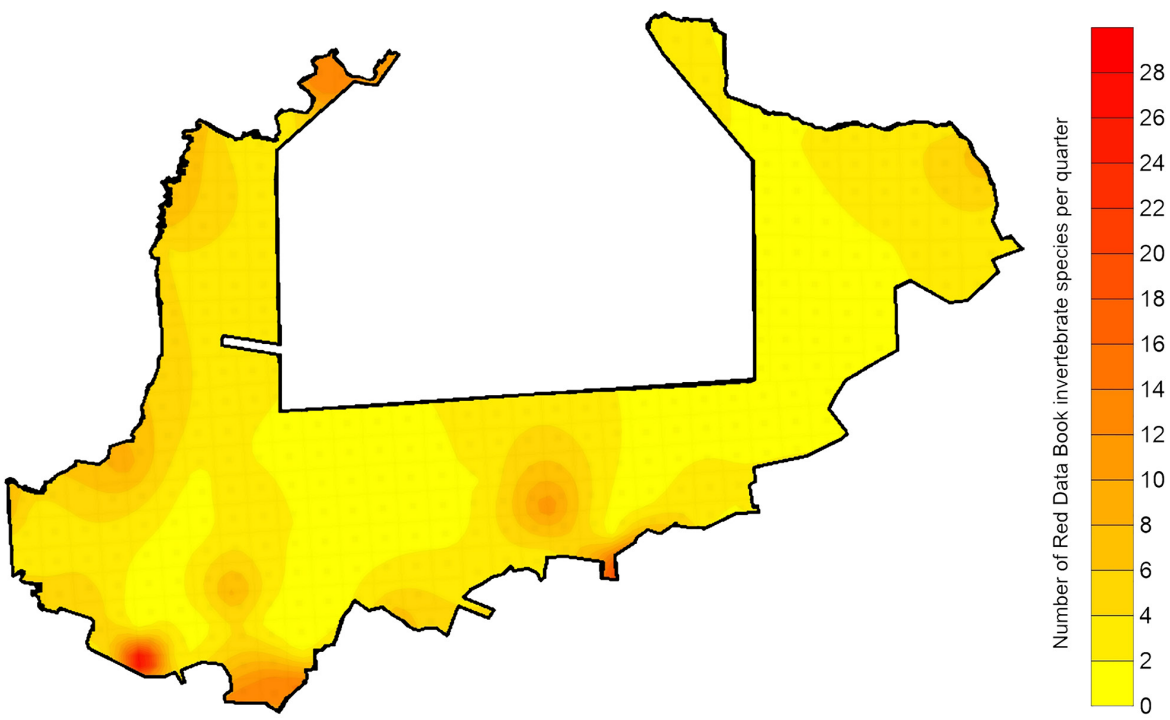

Fig. 4. Contour map showing the number of the Red Data Book invertebrate species per quarter in the Mordovia State Nature Reserve 
in the Mordovia State Nature Reserve (Fig. 5) (Bengtsson et al. 2000, Kovac et al. 2018). This is clearly explained by the predominance of forest habitats (89.3\% of total Protected Area) in the Mordovia State Nature Reserve. There were remarkably fewer Red Data Book invertebrate species in Sphagnum mires (18 records), floodplain meadows (9 records), water bodies and their shores (8 records), man-made habitats (7 records). In addition, Fig. 5 demonstrates a considerably high number of Red Data Book invertebrates within mixed forests, as well as on edges and glades of mixed forests. This is in accordance with data of other investigations (e.g., SüMEgr et al. 2012, NovenKo et al. 2018) that reported high species diversity in ecotone plant communities.

In the Mordovia State Nature Reserve, floodplain broad-leaved forests (linden forests and oak forests) are of special interest. This is a unique refugium for the forest fauna and flora that remained little affected by human activity for many centuries. The largest portion of such forests is located in the western, southwestern and northern parts of the Protected Area. In these areas, centuries-old Quercus robur, large Tilia cordata and Fraxinus excelsior L. trees still survive. There are numerous fallen and gradually decaying trunks of these trees, extremely important for the persistence of saproxylic insects. Additionally, floodplains form unique conditions for numerous saproxylic beetles and numerous species associated with broad-leaved forests and which are known only in these areas. Of special interest are some species included the current edition of the Red Data Book of the Russian Federation (Danilov-Danilyan 2001) and species recommended for inclusion in its second edition (ILYASHENко et al. 2018). They are: Ceruchus chrysomelinus (Hochenwarth, 1785), Lucanus cervus (Linnaeus, 1758), Trypocopris vernalis (Linnaeus, 1758), Osmoderma barnabita Motschulsky, 1845, Protaetia speciosissima (Scopoli, 1786), Protaetia fieberi (Kraatz, 1880), Elater ferrugineus Linnaeus, 1758 (Ruchin \& Egorov 2017b, 2018a). Also, four species (Allonyx quadrimaculatus (Schaller, 1783), Leptura aurulenta Fabricius, 1793, Nothochrysa fulviceps (Stephens, 1836), Catocala promissa ([Denis et Schiffermüller], 1775)). These speceis are confined to these areas and are known only in the Mordovia State Nature Reserve in Russia (Bolshakov \& Ruchin 2016, Ruchin \& Egorov 2018b,d, Tomaszewska et al. 2018).

Meadows cover about 1\% of the total Protected Area. They are located predominantly in the western and southwestern parts of the Mordovia State Nature Reserve and around cordons. For this, cordons play a very important role in biodiversity maintenance. The cordons previously served as the residence of the Mordovia Reserve officers who constantly grazed cattle or mowed grass on the nearby meadows. Typically, the number of animals grazed was quite low. Grazing and mowing brought certain benefits, counteracting the overgrowth of meadows by woody and weed-meadow plants. Exactly these conditions allowed the persistence of a Parnassius apollo population for a long time. However, it has gradually compromised by the decline of Sedum maxi- 
mum (L.) Hoffm. populations, a feeding plant for P. apollo larvae (Ruchin \& Grushut KIN 2018). Within the Mordovia State Nature Reserve, populations of the following xerophilic species survive in meadow habitats: Myrmeleotettix maculatus (Thunberg, 1815), Sphingonotus caerulans caerulans (Linnaeus, 1767), Psophus stridulus (Linnaeus, 1758) (Orthoptera), Parnopes grandior (Pallas, 1771) (Hymenoptera), Dysauxes ancilla (Linnaeus, 1767), Panthea coenobita (Esper, 1785) (Lepidoptera). Due to the particular microclimatic conditions and mesophilisation processes, some meadow sites of the Mordovia State Reserve (especially in the Moksha river floodplain) are the only habitats for the lepidopterans Phragmataecia castaneae (Hübner, 1790), Zygaena centaureae Fischer von Waldheim, 1832, Carcharodus alceae (Esper, 1780), Melitaea phoebe (Goeze, 1779), Chortobius hero (Linnaeus, 1760), Lycaena hippothoe (Linnaeus, 1760).

Figure 6 presents values of the Representativeness Index (RI) for the Red Data Book invertebrate species of the Mordovia State Nature Reserve. Among all studied taxa, RI values of Neuroptera, Heteroptera, and Mollusca species were less than $50 \%$. However, these taxa included the smallest number of the Red Data Book invertebrate species in the Mordovia State Nature Reserve. These are one Neuroptera species (Nothochrysa fulviceps (Stephens, 1836)), two Heteroptera species (Cercopis vulnerata Rossi, 1807, Pygolampis bidentata (Goeze, 1778)), and two Mollusca species (Acroloxus lacustris (Linnaeus, 1758), Planorbis carinatus O.F. Müller, 1774). Orthoptera have an intermediate position because they include species with both high (Podisma pedestris (Linnaeus, 1758), RI $=100 \%$ ) and low (Myrmeleotettix maculatus (Thunberg, 1815), $\mathrm{RI}=23.1 \%$; Stenobothrus nigromaculatus (Herrich-Schaffer, 1840), RI = 16.7\%) RI

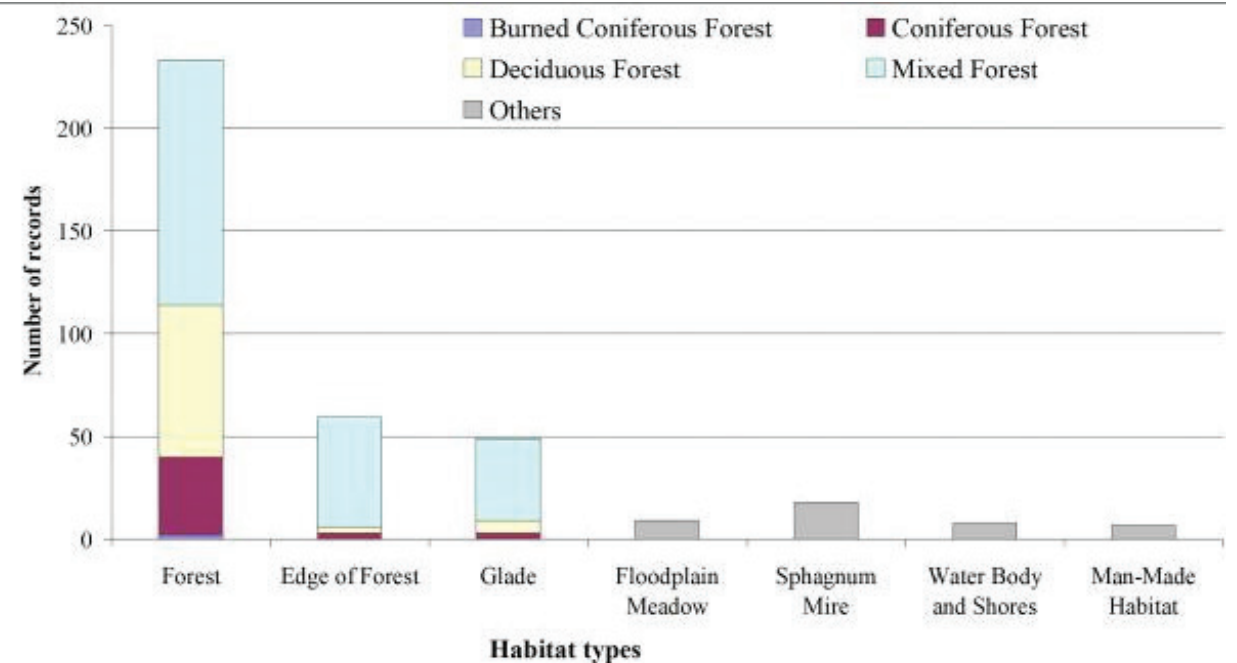

Fig. 5. Habitat preferences of Red Data Book invertebrate species in the Mordovia State Nature Reserve 
values. Finally, each of the four remaining orders (Coleoptera, Lepidoptera, Hymenoptera, Diptera) contains at least $40 \%$ Red Data Book species with RI values equal to or higher than $50 \%$. Coleoptera and Lepidoptera are the groups with the highest number (31 and 70 taxa, respectively) of the Red Data Book invertebrate species known in the Mordovia State Nature Reserve.

The conservation value of a Protected Area is obviously increased by the species that are known for only the concerned area within a region (RUCHIN \& Kurmaeva 2010, Mikhailenko \& Ruchin 2015, Ruchin \& Egorov 2015, 2017b, 2018a, Bolshakov \& Ruchin 2016). On the basis of the RI values, we distinguish a group of Red Data Book invertebrate species of the region (Republic of Mordovia), which are known here only in the Mordovia State Nature Reserve (i.e., RI=100\%). They are represented by one Orthoptera species (Podisma pedestris), six Coleoptera species (Lebia marginata (Geoffroy, 1785), Sphaerites glabratus (Fabricius, 1792), Elater ferrugineus Linnaeus, 1758, Allonyx quadrimaculatus (Schaller, 1783), Evodinellus borealis (Gyllenhal, 1827), Leptura aurulenta Fabricius, 1793), and 20 Lepidoptera species (Eversmannia exornata (Eversmann, 1837), Arichanna melanaria (Linnaeus, 1758), Phyllodesma ilicifolia (Linnaeus, 1758), Smerinthus caecus (Ménétriès, 1857), Cerura erminea (Esper, 1783), Ptilodon cucullina ([Denis et Schiffermüller], 1775), Odontosia carmelita (Esper, 1799), Clostera anastomosis (Linnaeus, 1758), Dicallomera fascelina (Linnaeus, 1758), Calliteara abietis ([Denis et Schiffermüller], 1775), Eilema depressum (Esper, 1787), Lithosia quadra (Linnaeus, 1758), Rhyparia purpurata (Linnaeus, 1758), Dysauxes ancilla (Linnaeus, 1767), Minucia lunaris ([Denis et Schiffermüller], 1775), Panthea coenobita (Esper, 1785), Anarta myrtilli (Linnaeus, 1760), Boloria aquilonaris (Stichel, 1908), Scolitantides orion (Pallas, 1771), Agriades optilete (Knoch, 1781)). Thus, the special protection regime and habitat diversity of the Mordovia State Nature Reserve is important to counteract the regional extinction of these 27 species in the Republic of Mordovia.

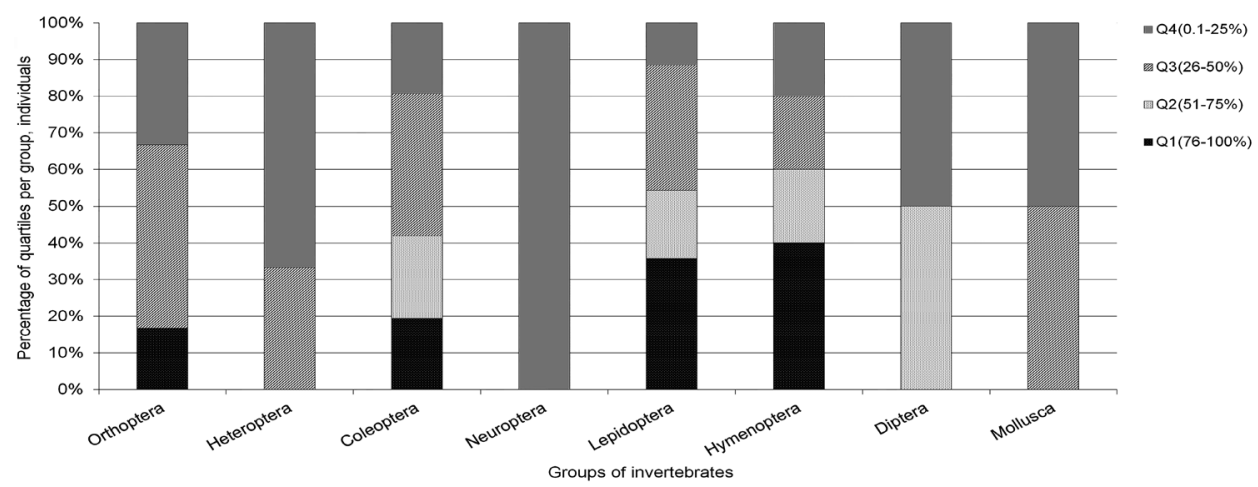

Fig. 6. Proportions of Representativeness Index values for the Red Data Book invertebrates in the Mordovia State Nature Reserve 


\section{CONCLUSIONS}

The main cause for Protected Areas establishment is a need to protect threatened and rare plants and animals from extinction. However, in most cases, conservation measures are focused on the largest and most remarkable animals (Shi et al. 2008, Zhang et al. 2015, Mizin et al. 2018, SAmson \& RAMAKRishnan 2018) and plants (BAuer et al. 2016, WicAKsono et al. 2016). Although conservation of these species is undoubtedly important, we should not ignore a need to study and preserve all imperiled organisms. Globally or regionally threatened invertebrate species play an important role for ecosystem functioning, yet their remain less considered in conservation programs. Protected Areas, as islands of the least destructed natural ecosystems, are main refugia of invertebrate diversity, including threatened and rare species.

In this study, we demonstrated a significant increase in the known diversity of invertebrate species with increasing research investigations in a limited area, the Mordovia State Nature Reserve. Out of the more than 6,000 invertebrate species revealed during 1936-2018, we considered 120 taxa as Red Data Book invertebrates in the Republic of Mordovia. We showed a remarkable decrease in known species diversity when moving away from research stations (e.g., cordons or settlements). This is probably because $58.3 \%$ of the Red Data Book species were found in the recent ten years and are confirmed predominantly only by 1-2 records. Hence, further surveys of areas remote from cordons could reveal a more widespread distribution of these invertebrate species. Most of the Red Data Book invertebrate species in the Mordovia State Nature Reserve are confined to forest ecosystems with many records in ecotone communities (mixed forests, glades, and edges of mixed forests). Despite the small area, oligotrophic Sphagnum mires and floodplain meadows were also important refugia for Red Data Book invertebrate species of the Republic of Mordovia. We found four and 27 invertebrate species known only from the Mordovia State Nature Reserve for the whole Russia and the Republic of Mordovia, respectively. However, we can expect that these species will be found outside the Mordovia Reserve during further investigations in the Republic of Mordovia and Russia as a whole. Finally, we propose to promote the knowledge of the whole invertebrate fauna of the Mordovia State Nature Reserve and the whole Republic of Mordovia to identify biodiversity hotspots and coldspots at different spatial scales.

Acknowledgements - We are grateful to two anonymous reviewers for their helpful comments and corrections. Anna V. Gubina (Joint Directorate of the Mordovia State Nature Reserve and National Park «Smolny», Russia) is acknowledged for the help in correcting the text into English. 


\section{REFERENCES}

Anufriev, G. A. (2016): Middle-summer cicadinas fauna (Hemiptera, Cicadina) of the Vitimsky Reserve (Irkutsk region). - Nature Conservation Research 1(1): 65-77. https:// doi.org/10.24189/ncr.2016.006 [In Russian]

Anufriev, G. A. (2017): Spittlebugs of genus Aphrophora Germ. (Hemiptera, Cicadinea, Aphrophoridae) in European Russia based on studies in the Mordovia State Nature Reserve. - Proceedings of the Mordovia State Nature Reserve 18: 3-16. [In Russian]

Astradamov, V. I. (ed.). (2005): Red Data Book of the Republic of Mordovia. Vol. 2: Animals. Publisher of the Mordovia State University, Saransk, 336 pp. [In Russian]

Bauer, U., Rembold, K. \& Grafe, T. U. (2016): Carnivorous Nepenthes pitcher plants are a rich food source for a diverse vertebrate community. - Journal of Natural History 50(7-8): 483-495. https://doi.org/10.1080/00222933.2015.1059963

Belle, E., Kingston, N., Burgess, N., Sandwith, T., Ali, N. \& MacKinnon, K. (eds.). (2018): Protected Planet Report 2018. UNEP-WCMC, IUCN and NGS, Cambridge UK; Gland, Switzerland; and Washington, D.C., USA, 56 pp.

Bengtsson, J., Nilsson, S. G., Franc, A. \& Menozzi, P. (2000): Biodiversity, disturbances, ecosystem function and management of European forests. - Forest Ecology and Management 132: 39-50.

Bezina, O. V. (2014): Terrestrial mollusks of the Mordovia State Nature Reserve. - Proceedings of the Mordovia State Nature Reserve 12: 400-410. [In Russian]

Bolshakov, L. V. \& Ruchin, A. B. (2016): Review of lepidopterans (Insecta: Lepidoptera) recommended for inclusion into the second edition of the Red Data Book of the Republic of Mordovia. - Proceedings of the Mordovia State Nature Reserve 16: 118-268. [In Russian]

Bolshakov, L. V., Ruchin, A. B., Piskunov, V. I. \& Semishin, G. B. (2014): To the fauna of Lepidoptera in the Republic of Mordovia. Addition 3. - Eversmannia 38: 19-27.

Bolshakov, L. V., Ruchin, A. B., Piskunov, V. I. \& Semishin, G. B. (2017): To the fauna of Lepidoptera in the Republic of Mordovia. Addition 5. - Eversmannia 51-52: 40-46.

Bolshakov, L. V., Ruchin, A. B., Piskunov, V. I. \& Semishin, G. B. (2018): To the fauna of Lepidoptera in the Republic of Mordovia. Addition 6. - Eversmannia 54: 49-54. [In Russian]

Bouchard, P., Smith, A. B. T., Douglas, H., Gimmel, M. L., Brunke, A. J. \& Kanda, K. (2017): Biodiversity of Coleoptera. Pp. 337-417. In: Insect biodiversity: science and society. Vol. 1. 2nd ed. - John Wiley \& Sons Ltd. https://doi.org/10.1002/9781118945568.ch11

Budaeva, I. A. \& Ruchin, A. B. (2014): To the fauna of blackflies (Diptera: Simuliidae) of the Republic of Mordovia (Russia). - Caucasian Entomological Bulletin 10(1): 155-159. [In Russian]

Budaeva, I. A. \& Ruchin, A. B. (2016): To the fauna of deer flies (Diptera: Tabanidae) of the Republic of Mordovia. - Belgorod State University Scientific Bulletin. Natural Sciences 35(11): 85-93. [In Russian]

Butchart, S. H. M., Walpole, M., Collen, B., van Strien, A., Scharlemann, J. P., Almond, R. E., Baillie, J. E., Bomhard, B., Brown, C., Bruno, J., Carpenter, K. E., Carr, G. M., Chanson, J., Chenery, A. M., Csirke, J., Davidson, N. C., Dentener, F., Foster, M., Galli, A., Galloway, J. N., Genovesi, P., Gregory, R. D., Hockings, M., Kapos, V., Lamarque, J. F., Leverington, F., Loh, J., McGeoch, M. A., McRae, L., Minasyan, A., Hernández Morcillo, M., Oldfield, T. E., Pauly, D., Quader, S., Revenga, C., Sauer, J. R., Skolnik, B., Spear, D., Stanwell-Smith, D., Stuart, S. N., Symes, A., Tierney, M., Tyrrell, T. D., Vié, J. C. \& WAtson, R. (2010): Global biodiversity: indicators of recent declines. - Science 328: 1164-1168. https://doi.org/10.1126/science.1187512 
Cardoso, P., Borges, P. A. V., Triantis, K. A., Ferrández, M. A. \& Martín, J. L. (2011): Adapting the IUCN Red List criteria for invertebrates. - Biological Conservation 144: 2432-2440. https://doi.org/10.1016/j.biocon.2011.06.020

Cardoso, P., Borges, P. A. V., Triantis, K. A., Ferrández, M. A. \& Martín, J. L. (2012): The underrepresentation and misinterpretation of invertebrates in the IUCN Red List. Biological Conservation 149: 147-148. https://doi.org/10.1016/j.biocon.2012.02.011

Carignan, V. \& Villard, M. (2002): Selecting indicator species to monitor ecological integrity: a review. - Environmental Monitoring and Assessment 78: 45-61.

Chikhlyaev, I. \& Ruchin, A. (2014): The helminth fauna study of European common brown frog (Rana temporaria Linnaeus, 1758) in the Volga basin. - Acta Parasitologica 59(3): 459-471. https://doi.org/10.2478/s11686-014-0268-5

Chikhlyaev, I. V., Ruchin, A. B. \& Fayzulin, A. I. (2016): The helminth fauna study of European common toad in the Volga Basin. - Nature, Environment and Pollution Technology 15(3): 1103-1109.

Chursina, M. A. \& Ruchin, A. B. (2018a): A checklist of Bombyliidae (Diptera) from Mordovia, Russia and variation of wing shape in Bombylius species. - Biodiversitas 19(6): 2147-2156. https://doi.org/10.13057/biodiv/d190622

Chursina, M. A. \& Ruchin, A. B. (2018b): A checklist of Syrphidae (Diptera) from Mordovia, Russia. - Halteres 9: 57-73. https://doi.org/10.5281/zenodo.1255874

Danilov-Danilyan, V. I. (ed.). (2001): Red Data Book of Russian Federation. Animals. Astrel, Moscow, 862 pp. [In Russian]

Dirzo, R., Young, H. S., Galetti, M., Ceballos, G., Isaac, N. J. B. \& Collen, B. (2014): Defaunation in the Anthropocene. - Science 345: 401-406.

Egorov, L. V. \& Ruchin, A. B. (2009): About status of some beetle species (Insecta, Coleoptera) in the Red Data Book of the Republic of Mordovia. Pp. 21-39. In: Rare animals of the Republic of Mordovia: materials for maintenance of the Red Data Book of the Republic of Mordovia for 2009. - Publisher of the Mordovia State University, Saransk. [In Russian]

Egorov, L. V. \& Shapovalov, A. M. (2017): On the distribution of a poorly known longicorn beetle, Phymatodes abietinus Plavilstshikov et Lurie, 1960 (Coleoptera, Cerambycidae: Cerambycinae). - Entomological Review 97: 353-356.

Fеоктіsтov, V. F. (2011): The list of insect species discovered for the first time in the Mordovia State Nature Reserve and in adjacent territories. - Mordovia University Bulletin 4: 83-89. [In Russian]

Halffter, G. (2005): Towards a culture of biodiversity conservation. - Acta Zoologica Mexicana 21(002): 133-153.

Ilyashenko, V. Yu., Shatalkin, A. I., Kuvaev, A. V., Komendatov, A. Yu, Britaev, T. A., Kosyan, A. R., Pavlov, D. S., Shilin, N. I., Ananjeva, N. B., Tuniyev, B. S., Semenov, D. V., Syroechrovskiy, E. E., Morozov, V. V., Mishchenko, A. L., Rozhnov, V. V. \& Poyarkov, A. D. (2018): Rare and endangered animals of Russia. Materials towards the Red Data Book of the Russian Federation. KMK Scientific Press Ltd., Moscow, 112 pp. [In Russian]

Kareiva, P. \& Marvier, M. (2003): Conserving biodiversity coldspots. - American Scientist 91(4): 344-351.

Kornev, I. I., Aksenenko, E. V. \& Ruchin, A. B. (2016): New data of the fauna and distribution of the genus Bibio Geoffroy, 1762 (Diptera: Bibionidae) of the Republic of Mordovia (Russia). - Ukrainska Entomofaunistyka 7(4): 55-56. [In Russian]

Kovac, M., Hladnik, D. \& Kutnar, L. (2018): Biodiversity in (the Natura 2000) forest habitats is not static: its conservation calls for an active management approach. - Journal for Nature Conservation 43: 250-260. https://doi.org/10.1016/j.jnc.2017.07.004 
Legalov, A. A., Egorov, L. V. \& Ruchin, A. B. (2014): First record of Mesauletobius pubescens (Kiesenwetter, 1851) (Coleoptera, Rhynchitidae) in Russia. - Euroasian Entomological Journal 13(4): 400. [In Russian]

Mace, G. M., Collar, N. J., Gaston, K. J., Hilton-Taylor, C., Akçakaya, H. R., LeaderWilliams, N., Milner-Gulland, E. J. \& Stuart, S. N. (2008): Quantification of extinction risk: IUCN's system for classifying threatened species. - Conservation Biology 22: 1424-1442. https://doi.org/10.1111/j.1523-1739.2008.01044.x

Makarkin, V. N. \& Ruchin, A. B. (2010): Materials on the green lacewing fauna of Mordovia (Neuroptera, Chrysopidae). - Mordovia University Bulletin 1: 123-127. [In Russian]

Makarkin, V. N. \& Ruchin, A. B. (2014): A contribution to the knowledge of Neuroptera and Raphidioptera of Mordovia (Russia). - Caucasian Entomological Bulletin 10(1): 111-117. [In Russian]

Makarkin, V. N. \& Ruchin, A. B. (2015): The extent of the knowledge of lacewings and snakeflies of the Republic of Mordovia, with recommendations for inclusion in the main lists of protected taxa. - Proceedings of the Mordovia State Nature Reserve 15: 133141. [In Russian]

Mandelshtam, M. Yu. \& Egorov, L. V. (2017): Materials to the knowledge of bark beetles (Coleoptera, Curculionidae, Scolytinae) of the Mordovia State Nature Reserve. Report 1. - Proceedings of the Mordovia State Nature Reserve 18: 274-278. [In Russian]

Margules, C. R. \& Pressey, R. L. (2000): Systematic conservation planning. - Nature 405: 243-253.

Martin-López, B., Montes, C. \& Benayas, J. (2007): The non-economic motives behind the willingness to pay for biodiversity conservation. - Biological Conservation 139: 67-82.

Maynew, P. J. (2018): Explaining global insect species richness: lessons from a decade of macroevolutionary entomology. - Entomologia Experimentalis et Applicata 166(4): 225250. https://doi.org/10.1111/eea.12673

Mikhailenko, A. P. \& Ruchin, A. B. (2015): About Orthoptera species recommended to be protected in the Republic of Mordovia. - Proceedings of the Mordovia State Nature Reserve 15: 143-155. [In Russian]

MishrA, A. K. (2013): Effect of rain gauge density over the accuracy of rainfall: a case study over Bangalore, India. - SpringerPlus 2(1): 311. https://doi.org/10.1186/2193-1801-2-311

Mizin, I. A., Sipko, T. P., Davydov, A. V. \& Gruzdev, A. R. (2018): The wild reindeer (Rangifer tarandus: Cervidae, Mammalia) on the Arctic islands of Russia: a review. - Nature Conservation Research 3(3): 1-14. https://doi.org/10.24189/ncr.2018.040

Mokrousov, M. V., Ruchin, A. B. \& Egorov, L. V. (2013): The wasp fauna of Mordovia State Nature Reserve and adjacent territories. - Proceedings of the Mordovia State Nature Reserve 11: 193-205. [In Russian]

Novenko, E. Yu., Zyuganova, I. S., Volkova, E. M. \& Dyuzhova, K. V. (2018): A 7000year pollen and plant macrofossil record from the Mid-Russian Upland, European Russia: vegetation history and human impact. - Quaternary International. https://doi. org/10.1016/j.quaint.2017.11.025

Novenko, E. Y., Tsyganov, A. N., Payne, R. J., Mazei, N. G., Volkova, E. M., Chernyshov, V. A., Kupriyanov, D. A. \& Mazei, Y. A. (2017): Vegetation dynamics and fire history at the southern boundary of the forest vegetation zone in European Russia during the middle and late Holocene. - Holocene 28(2): 308-322. https://doi. org/10.1177/0959683617721331

Pacheco, J. F. \& Olmos, F. (2005): Birds of a latitudinal transect in the Tapajós-Xingu interfluvium, eastern Brazilian Amazonia. - Revista Brasileira de Ornitologia 13: 29-46. 
Pentinsaari, M., Hebert, P. D. N. \& Mutanen, M. (2014): Barcoding Beetles: A Regional Survey of 1872 Species Reveals High Identification Success and Unusually Deep Interspecific Divergences. - PLOS ONE 9(9): e108651. https://doi.org/10.1371/journal. pone. 0108651

Plavilshchikov, N. N. (1964): A list of insect species found on the territory of the Mordovia State Nature Reserve. - Proceedings of the Mordovia State Nature Reserve 2: 105-134. [In Russian]

Ramos, M. A., Lobo, J. M. \& Esteban, M. (2001): Ten years inventorying the Iberian fauna: results and perspectives. - Biodiversity and Conservation 10: 19-28.

Rodrigues, A. S. L., Andelman, S. J., Bakarr, M. I., Boitani, L., Brooks, T. M., Cowling, R. M., Fishrool, L. D. C., da Fonseca, G. A. B., Gaston, K. J., Hoffmann, M., Long, J. S., Marquet, P. A., Pilgrim, J .D., Pressey, R. L., Schipper, J., Sechrest, W., Stuart, S. N., Underhill, L. G., WALler, R. W., Watts, M. E. J. \& YAN, X. (2004): Effectiveness of the global protected area network in representing species diversity. - Nature 428: 640-643.

Rodrigues, A. S. L., Pilgrim, J. D., Lamoreux, J. F., Hoffmann, M. \& Brooks, T. M. (2006): The value of the IUCN Red List for conservation. - Trends in Ecology E Evolution 21: 71-76. https://doi.org/10.1016/j.tree.2005.10.010

Ruchin, A. B. (2011): First additional materials towards the entomofauna of the Mordovia State Nature Reserve. - Proceedings of the Mordovia State Nature Reserve 9: 150-182. [In Russian]

Ruchin, A. B. (2015a): List of invertebrates (Invertebrata) of the Mordovia State Nature Reserve (ex. Insecta - Ectognatha). - Proceedings of the Mordovia State Nature Reserve 13: 334-350. [In Russian]

Ruchin, A. B. (2015b): Second additional materials on the insect fauna of the Mordovia State Nature Reserve. - Proceedings of the Mordovia State Nature Reserve 13: 351-398. [In Russian]

Ruchin, A. B. (2017): Third additional materials to the entomofauna of the Mordovia State Nature Reserve. - Proceedings of the Mordovia State Nature Reserve 19: 161-181. [In Russian]

Ruchin, A. B. (2018): Biology and distribution of the Clouded Apollo Parnassius mnemosyne (Linnaeus, 1758) (Lepidoptera: Papilionidae), a rare butterfly in the Republic of Mordovia, Russia. - Journal of Threatened Taxa 10(7): 11980-11983. https://doi.org/10.11609/ jot.3709.10.7.11980-11983

Ruchin, A. B. \& Artaev, O. N. (2016): On expansion of the distribution range of some scoliid wasps (Scoliidae, Hymenoptera, Insecta) in the Middle Volga region. - Research Journal of Pharmaceutical, Biological and Chemical Sciences 7(3): 2110-2115.

Ruchin, A. B. \& Egorov, L. V. (2015): Beetle species (Coleoptera) recommended to be protected in the Republic of Mordovia (main list of protected taxa). - Proceedings of the Mordovia State Nature Reserve 15: 70-104. [In Russian]

Ruchin, A. B. \& Egorov, L. V. (2017a): New and interesting species of Coleoptera in the Republic of Mordovia. - Eversmannia 51-52: 21-26. [In Russian]

Ruchin, A. B. \& Egorov, L. V. (2017b): Overview of insect species included in the Red Data Book of Russian Federation in the Mordovia State Nature Reserve. - Nature Conservation Research 2(Suppl. 1): 2-9. https://doi.org/10.24189/ncr.2017.016 [In Russian]

Ruchin, A. B. \& Egorov, L. V. (2018a): Beetles (Insecta, Coleoptera), collected using fermental crown trap in the Republic of Mordovia. Report 1. Mordovia State Nature Reserve. - Scientific Proceedings of the State Nature Reserve «Prisursky» 33: 209-215. [In Russian] 
Ruchin, A. B. \& Egorov, L. V. (2018b): Discovery of Allonyx quadrimaculatus (Schaller, 1783) (Coleoptera Cleridae Clerinae) in Russia. - Redia 101: 143-146. https://doi. org/10.19263/REDIA-101.18.19

Ruchin, A. B. \& Egorov, L. V. (2018c): Fauna of longicorn beetles (Coleoptera: Cerambycidae) of Mordovia. - Russian Entomological Journal 27(2): 161-177. https://doi. org/10.15298/rusentj.27.2.07

Ruchin, A. B. \& Egorov, L. V. (2018d): Leptura aurulenta (Coleoptera, Cerambycidae), a new record of a very rare species in Russia. - Nature Conservation Research 3(1): 88-91. https://doi.org/10.24189/ncr.2018.003

Ruchin, A. B. \& Egorov, L. V. (2018e): On distribution of Mimela holosericea (Fabricius, 1787) (Insecta, Scarabaeoidea, Scarabaeidae, Rutelinae) in Russia and adjacent territories. - Journal of Entomological and Acarological Research 50: 7390. https://doi.org/10.4081/ jear.2018.7390

Ruchin, A. B., Egorov, L. V. \& Semishin, G. B. (2018): Fauna of click beetles (Coleoptera: Elateridae) in the interfluve of Rivers Moksha and Sura, Republic of Mordovia, Russia. - Biodiversitas 19(4): 1352-1365. https://doi.org/10.13057/biodiv/d190423

Ruchin, A. B. \& Grishutkin, G. F. (2018): Biology and distribution of Parnassius apollo (Linnaeus, 1758) a rare species in Mordovia Republic, Russia. - Biodiversitas 19(2): 431436. https://doi.org/10.13057/biodiv/d190210

Ruchin, A. B. \& Kurmaeva, D. K. (2010): On rare insects of Mordovia included in the Red Book of the Russian Federation. - Entomological Review 90(6): 712-717. https://doi. org/10.1134/S0013873810060060

Ruchin, A. B. \& Makarkin, N. V. (2017): Neuroptera and Raphidioptera in the Mordovia State Nature Reserve. - Nature Conservation Research 2(2): 38-46. https://doi. org/10.24189/ncr.2017.001 [In Russian]

Ruchin, A. B. \& Mikhailenko, A. P. (2018): Fauna of mantids and orthopterans (Insecta: Mantodea, Orthoptera) of the Mordovia State Nature Reserve, Russia. - Biodiversitas 19(4): 1194-1206. https://doi.org/10.13057/biodiv/d190403

Ruchin, A. B. \& Nikolaeva, A. M. (2015): Recommendations towards the preparation of the list of rare and monitored species of bugs (Insecta, Heteroptera) in the Republic of Mordovia. - Proceedings of the Mordovia State Nature Reserve 15: 156-162. [In Russian]

Ruchin, A. B., Ryzhov, M. K., Artaev, O. N. \& Khapugin, A. A. (2013): New records of Argiope bruennichi (Scopoli, 1772) (Aranei: Araneidae) from Mordovia and adjacent regions of Russia. - Arthropoda Selecta 22(4): 361-362.

Ruchin, A. B., Chiкhljaev, I. V. \& Lukijanov, S. V. (2009): Analysis of helminthofauna of common spaedfoot Pelobates fuscus (Laurenti, 1768) and moor frog Rana arvalis Nilsson, 1842 (Amphibia: Anura) at their joint habitation. - Parazitologiya 43(3): 240-247. [In Russian]

SAMSON, A. \& RAMAKRISHnAN, B. (2018): Population status, habitat selection and people's perception on Pavo cristatus (Aves: Phasianidae) in Sigur Plateau, the Nilgiris, Tamil Nadu, India. - Nature Conservation Research 3(1): 80-87. https://doi.org/10.24189/ncr.2018.010

Samways, M. J. (2005): Insect diversity conservation. Cambridge University Press, Cambridge. https://doi.org/10.1017/CBO9780511614163

Semenov, V. B. (2016): New data on the fauna of Staphylinidae (Coleoptera) of Mordovia. Proceedings of the Mordovia State Nature Reserve 16: 431-434. [In Russian]

Shi, H., Liu, N., CaO, L. \& Barter, M. (2008): Status of the East Asian population of the Dalmatian Pelican Pelecanus crispus: The need for urgent conservation action. - Bird Conservation International 18(2): 181-193. https://doi.org/10.1017/S0959270908000178 
Silveira, L. F., Olmos, F. \& Long, A. (2003): Birds in Atlantic Forest Fragments in north-east Brazil. - Cotinga 20: 32-46.

Stork, N. E., Samways, M. J. \& Eeley, H. A. C. (1996): Inventorying and monitoring biodiversity. - Trends in Ecology \& Evolution 11: 39-40.

Sтоүко, T. G. \& Komarova, E. V. (2015): About two terrestrial mollusks recommended to be protected in the Republic of Mordovia. - Proceedings of the Mordovia State Nature Reserve 15: 224-226. [In Russian]

SüMegi, P., Persaits, G. \& Gulyás, S. (2012): Woodland-grassland ecotonal shifts in environmental mosaics: lessons learnt from the environmental history of the Carpathian Ba$\sin$ (Central Europe) during the Holocene and the last ice age based on investigation of paleobotanical and mollusk remains. Pp. 17-57. In: Myster, R. (ed.): Ecotones between forest and grassland. - Springer, New York. https://doi.org/10.1007/978-1-4614-3797-0_2

Susнко, G. G. (2017): Diversity and species composition of beetles in the herb-shrub layer of a large isolated raised bog in Belarus. - Mires and Peat 19(10): 1-14. https://doi. org/10.19189/MaP.2017.OMB.266

Tereshikin, I. S. \& Tereshinan, L. V. (2006): Vegetation of the Mordovia Reserve. Successive series of the successions. - Proceedings of the Mordovia State Nature Reserve 7: 186-287. [In Russian]

Thuiller, W. (2007): Biodiversity-climate change and the ecologist. - Nature 448: 550-552.

Tomaszewska, W., Egorov, L. V., Ruchin, A. B. \& Vlasov, D. V. (2018): First record of Clemmus troglodytes (Coleoptera: Coccinelloidea, Anamorphidae) for the fauna of Russia. - Nature Conservation Research 3(3): 103-105. https://doi.org/10.24189/ncr.2018.016

Vargot, E. V., Khapugin, A. A., Chugunov, G. G. \& Grishutkin, O. G. (2016): Vascular plants of the Mordovia State Nature Reserve (an annotated species list). Commission of RAS on biodiversity conservation; IPEE RAS, Moscow, 68 pp. [In Russian]

Watson, J. E. M., Dudley, N., Segan, D. B. \& Hockings, M. (2014): The performance and potential of protected areas. - Nature 515: 67-73.

Wicaksono, A., Mursidawati, S., Sukamto, L. A. \& Teixeira da Silva, J. A. (2016): Rafflesia spp.: propagation and conservation. - Planta 244(2): 289-296. https://doi.org/10.1007/ s00425-016-2512-8

Young, R. P., Hudson, M. A., Terry, A. M. R., Jones, C. G., Lewis, R. E., Tatayah, V., ZuëL, N. \& Butchart, S. H. M. (2014): Accounting for conservation: Using the IUCN Red List Index to evaluate the impact of a conservation organization. - Biological Conservation 180: 84-96. https://doi.org/10.1016/j.biocon.2014.09.039

Zemoglyadchuk, A. V., Ruchin, A. B. \& Egorov, L. V. (2019): The annotated list of pintail beetles (Coleoptera, Mordellidae) of the Republic of Mordovia, with short review of the family in European Russia. - Zoologicheskii Zhurnal. [In press]

Zhang, L., Tian, Y., Guo, Q. X., Kou, X. J., Han, X. M., Miquelle, D. G., Oliver, C. D., Xu, R. M. \& GE, J. P. (2015): Amur tigers and leopards returning to China: direct evidence and a landscape conservation plan. - Landscape Ecology 31(3): 491-503.

Zografou, K., Kati, V., Grill, A., Wilson, R. J., Tzirkalli, E., Pamperis, L. N. \& HalLEY, J. M. (2014): Signals of Climate Change in Butterfly Communities in a Mediterranean Protected Area. - PLoS ONE 9(1): e87245. https://doi.org/10.1371/journal. pone. 0087245

Received January 10, 2019, accepted July 4, 2019, published November 22, 2019 
Table S1. The list of the Red Data Book invertebrate species known in the Mordovia State Nature Reserve (European Russia). RI = Representativeness index; RC2005 = Rarity category (according to AstRADAmov 2005), RC2001 = Rarity category (according to Danilov-Danilyan 2001).

\begin{tabular}{|c|c|c|c|c|}
\hline Species & Habitats & RI,\% & RC2005 & RC2001 \\
\hline \multicolumn{5}{|l|}{ Odonata } \\
\hline Anax imperator Leach, 1815 & WBS & 16.7 & 2 & 3 \\
\hline \multicolumn{5}{|l|}{ Orthoptera } \\
\hline Chorthippus pullus (Philippi, 1830) & MF & 50.0 & 3 & - \\
\hline Myrmeleotettix maculatus (Thunberg, 1815) & GMH, MMH & 23.1 & 3 & - \\
\hline Podisma pedestris (Linnaeus, 1758) & $\begin{array}{c}\mathrm{MF}, \mathrm{CF}, \mathrm{MMH}, \\
\mathrm{GMF}\end{array}$ & 100.0 & 1 & - \\
\hline Psophus stridulus (Linnaeus, 1758) & MF & 28.6 & 2 & - \\
\hline Sphingonotus caerulans caerulans (Linnaeus, 1767) & $\mathrm{BCF}, \mathrm{MMH}$ & 45.5 & 3 & - \\
\hline Stenobothrus nigromaculatus (H.-S., 1840) & ? & 16.7 & 4 & - \\
\hline \multicolumn{5}{|l|}{ Heteroptera } \\
\hline Cercopis vulnerata Rossi, 1807 & GMF, GDF & 50.0 & 4 & - \\
\hline Cicadetta montana (Scopoli, 1772) & GMF & 15.8 & 2 & - \\
\hline Pygolampis bidentata (Goeze, 1778) & GMF & 12.5 & 2 & - \\
\hline \multicolumn{5}{|l|}{ Coleoptera } \\
\hline Allonyx quadrimaculatus (Schaller, 1783) & DF & 100.0 & 3 & - \\
\hline Aromia moschata (Linnaeus, 1758) & DF & 26.7 & 3 & - \\
\hline Calosoma auropunctatum (Herbst, 1784) & $\mathrm{MMH}$ & 9.1 & 2 & - \\
\hline Calosoma investigator (Illiger, 1798) & $\mathrm{CF}, \mathrm{MF}$ & 18.8 & 3 & - \\
\hline Calosoma sycophanta (Linnaeus, 1758) & EMF & 10.0 & 3 & 2 \\
\hline Carabus aurolimbatus Dejean \& Boisduval, 1829 & FM & 33.3 & 4 & - \\
\hline Carabus clathratus Linnaeus, 1761 & DF, MF, FM & 35.0 & 3 & - \\
\hline Carabus nitens Linnaeus, 1758 & MF & 28.6 & 3 & - \\
\hline Carabus schoenherri Fischer von Waldheim, 1820 & DF & 40.0 & 3 & - \\
\hline Ceruchus chrysomelinus (Hochenwarth, 1785) & $\mathrm{MF}, \mathrm{DF}$ & 50.0 & 3 & 2 \\
\hline Copris lunaris (Linnaeus, 1758) & MF & 41.7 & 3 & - \\
\hline Dytiscus latissimus Linnaeus, 1758 & WBS & 33.3 & 3 & 2 \\
\hline Elater ferrugineus Linnaeus, 1758 & $\mathrm{DF}, \mathrm{MF}$ & 100.0 & 1 & 2 \\
\hline Emus hirtus (Linnaeus, 1758) & EMF & 16.7 & 3 & - \\
\hline Evodinellus borealis (Gyllenhal, 1827) & MF, DF & 100.0 & 3 & - \\
\hline Gnorimus variabilis (Linnaeus, 1758) & $\mathrm{MF}, \mathrm{DF}, \mathrm{EDF}$ & 66.7 & 3 & - \\
\hline Hololepta plana (Sulzer, 1776) & DF & 20.0 & 3 & - \\
\hline Lebia marginata (Geoffroy, 1785) & EMF & 100.0 & 3 & - \\
\hline
\end{tabular}




\begin{tabular}{|c|c|c|c|c|}
\hline Species & Habitats & RI,\% & RC2005 & RC2001 \\
\hline Leptura aurulenta Fabricius, 1793 & $\mathrm{DF}$ & 100.0 & 3 & - \\
\hline Lucanus cervus (Linnaeus, 1758) & EMF & 25.0 & 3 & 2 \\
\hline Meloe variegatus Donovan, 1793 & EMF & 50.0 & 3 & - \\
\hline Necydalis major Linnaeus, 1758 & MF, DF & 35.7 & 3 & - \\
\hline Osmoderma barnabita Motschulsky, 1845 & $\mathrm{DF}, \mathrm{MF}$ & 44.4 & 2 & 2 \\
\hline Protaetia fieberi (Kraatz, 1880) & $\mathrm{MF}, \mathrm{DF}, \mathrm{EDF}$ & 66.7 & 3 & 2 \\
\hline Protaetia speciosissima (Scopoli, 1786)] & MF, DF & 53.8 & 2 & 2 \\
\hline Purpuricenus kaehleri (Linnaeus, 1758) & MF, DF & 62.5 & 1 & - \\
\hline Pyrochroa coccinea (Linnaeus, 1760) & $\mathrm{CF}, \mathrm{MF}$ & 28.6 & 3 & - \\
\hline Sphaerites glabratus (Fabricius, 1792) & $\mathrm{CF}, \mathrm{MF}$ & 100.0 & 3 & - \\
\hline Trypocopris vernalis (Linnaeus, 1758) & MF & 75.0 & 3 & 2 \\
\hline Valgus hemipterus (Linnaeus, 1758) & $\mathrm{MF}, \mathrm{CF}$ & 56.3 & 4 & - \\
\hline Velleius dilatatus (Fabricius, 1787) & MF, EDF, DF & 57.1 & 3 & - \\
\hline \multicolumn{5}{|l|}{ Neuroptera } \\
\hline Nothochrysa fulviceps (Stephens, 1836) & MF & 25.0 & 1 & - \\
\hline \multicolumn{5}{|l|}{ Lepidoptera } \\
\hline Acossus terebrus ([Den. et Schiff.], 1775) & DF & 60.0 & 3 & - \\
\hline Agriades optilete (Knoch, 1781) & SM & 100.0 & 1 & - \\
\hline Anarta myrtilli (Linnaeus, 1760) & $\mathrm{ECF}$ & 100.0 & 1 & - \\
\hline Arctia flavia (Fuessly, 1779) & MF & 50.0 & 4 & - \\
\hline Argynnis laodice (Pallas, 1771) & MF & 75.0 & 4 & - \\
\hline Arichanna melanaria (Linnaeus, 1758) & SM & 100.0 & 1 & - \\
\hline Boloria aquilonaris (Stichel, 1908) & SM & 100.0 & 1 & - \\
\hline Brenthis daphne ([Den. et Schiff.], 1775) & $\begin{array}{c}\text { GMF, DF, MF, } \\
\text { MMH, FM }\end{array}$ & 55.6 & 3 & - \\
\hline Callimorpha dominula (Linnaeus, 1758) & MF & 66.7 & 2 & - \\
\hline Calliteara abietis ([Den. et Schiff.], 1775) & $\mathrm{CF}$ & 100.0 & 1 & - \\
\hline Callopistria juventina (Stoll, 1782) & $\mathrm{CF}$ & 75.0 & 2 & - \\
\hline Carcharodus alceae (Esper, 1780) & FM & 25.0 & 3 & - \\
\hline Catocala promissa ([Den. et Schiff.], 1775) & MF & 16.7 & 3 & - \\
\hline Celaena haworthii (Curtis, 1829) & SM & 66.7 & 3 & - \\
\hline Cerura erminea (Esper, 1783) & MF & 100.0 & 3 & - \\
\hline Cerura vinula (Linnaeus, 1758) & DF & 71.4 & 3 & - \\
\hline Chortobius hero (Linnaeus, 1760) & $\begin{array}{c}\text { GMF, MF, EMF, } \\
\text { FM }\end{array}$ & 80.0 & 2 & - \\
\hline Clostera anastomosis (Linnaeus, 1758) & MF & 100.0 & 4 & - \\
\hline Comibaena bajularia ([Den. et Schiff.], 1775) & DF & 33.3 & 2 & - \\
\hline
\end{tabular}




\begin{tabular}{|c|c|c|c|c|}
\hline Species & Habitats & $\mathrm{RI}, \%$ & RC2005 & RC2001 \\
\hline Coscinia cribraria (Linnaeus, 1758) & MF & 66.7 & 3 & - \\
\hline Dicallomera fascelina (Linnaeus, 1758) & MF & 100.0 & 4 & - \\
\hline Dicycla oo (Linnaeus, 1758) & DF & 50.0 & 3 & - \\
\hline Driopa mnemosyne (Linnaeus, 1758) & GMF, GDF, EMF & 23.3 & 3 & - \\
\hline Dysauxes ancilla (Linnaeus, 1767) & DF & 100.0 & 4 & - \\
\hline Eilema depressum (Esper, 1787) & MF & 100.0 & 2 & - \\
\hline Epicallia villica (Linnaeus, 1758) & MF & 50.0 & 2 & - \\
\hline Erebia aethiops (Esper, [1777]) & EMF & 66.7 & 3 & - \\
\hline Eucharia festiva (Hufnagel, 1766) & MF & 66.7 & 1 & - \\
\hline Eudia pavonia (Linnaeus, 1758) & MF & 50.0 & 2 & - \\
\hline Eversmannia exornata (Eversmann, 1837) & EMF & 100.0 & 2 & - \\
\hline Fixsenia ilicis (Esper, [1779]) & MF & 40.0 & 3 & - \\
\hline Glaucopsyche alexis (Poda, 1761) & $\mathrm{CF}$ & 22.2 & 2 & - \\
\hline Iphiclides podalirius (Linnaeus, 1758) & $\begin{array}{c}\text { GMF, EMF, GCF, } \\
\text { FM }\end{array}$ & 53.8 & 5 & - \\
\hline Laothoe amurensis (Staudinger, 1892) & MF & 25.0 & 2 & - \\
\hline Lasiocampa quercus (Linnaeus, 1758) & MF, DF & 85.7 & 3 & - \\
\hline Lemonia dumi (Linnaeus, 1760) & MF & 50.0 & 3 & - \\
\hline Lithosia quadra (Linnaeus, 1758) & ECF & 100.0 & 1 & - \\
\hline Lycaena hippothoe (Linnaeus, 1760) & FM & 33.3 & 4 & - \\
\hline Melitaea cinxia (Linnaeus, 1758) & EMF & 68.8 & 3 & - \\
\hline Melitaea diamina (Lang, 1789) & EMF & 62.5 & 4 & - \\
\hline Melitaea phoebe (Goeze, 1779) & GMF, EMF, FM & 45.5 & 3 & - \\
\hline Minucia lunaris ([Den. et Schiff.], 1775) & MF & 100.0 & 3 & - \\
\hline Neptis sappho (Pallas, 1771) & MF & 28.6 & 3 & - \\
\hline Odontosia carmelita (Esper, 1799) & MF & 100.0 & 2 & - \\
\hline Pachigastria trifolii ([Den. et Schiff.], 1775) & $\mathrm{CF}, \mathrm{MF}, \mathrm{DF}$ & 100.0 & 4 & - \\
\hline Panthea coenobita (Esper, 1785) & MF & 100.0 & 1 & - \\
\hline Parnassius apollo (Linnaeus, 1758) & GMF & 14.3 & 2 & 3 \\
\hline Pelosia obtusa (Herrich-Schäffer, 1847) & WBS & 33.3 & 4 & - \\
\hline Pericallia matronula (Linnaeus, 1758) & MF & 33.3 & 4 & - \\
\hline Peridea anceps (Goeze, 1781) & MF & 50.0 & 3 & - \\
\hline Phragmataecia castaneae (Hübner, 1790) & FM & 50.0 & 4 & - \\
\hline Phyllodesma ilicifolia (Linnaeus, 1758) & MF & 100.0 & 4 & - \\
\hline Phyllodesma tremulifolia (Hübner, 1809) & DF & 50.0 & 2 & - \\
\hline Proserpinus proserpina (Pallas, 1772) & MF & 50.0 & 2 & - \\
\hline Pseudoterpna pruinata (Hufnagel, 1767) & $\mathrm{CF}$ & 83.3 & 2 & - \\
\hline
\end{tabular}




\begin{tabular}{lcccc}
\hline Species & Habitats & RI,\% & RC2005 & RC2001 \\
\hline Ptilodon cucullina ([Den. et Schiff.], 1775) & MF & 100.0 & 4 & - \\
Pyrgus alveus (Hübner, [1803]) & EMF & 50.0 & 3 & - \\
Rhodostrophia vibicaria (Clerck, 1759) & CF & 25.0 & 2 & - \\
Rhyparia purpurata (Linnaeus, 1758) & MF, DF & 100.0 & 3 & - \\
Sabra harpagula (Esper, 1786) & DF & 33.3 & 4 & - \\
Scolitantides orion (Pallas, 1771) & CF & 100.0 & 4 & - \\
Scotopterix moeniata (Scopoli, 1763) & CF & 50.0 & 2 & - \\
Scotopteryx mucronata (Scopoli, 1763) & CF & 87.5 & 2 & - \\
Setina irrorella (Linnaeus, 1758) & MF & 50.0 & 4 & - \\
Smerinthus caecus (Ménétriès, 1857) & MF & 100.0 & 1 & - \\
Spiris striata (Linnaeus, 1758) & MF, CF & 83.3 & 4 & - \\
Staurophora celsia (Linnaeus, 1758) & MF & 16.7 & 3 & - \\
Trichiura crataegi (Linnaeus, 1758) & MF & 50.0 & 3 & - \\
Watsonalla binaria (Hufnagel, 1767) & DF & 50.0 & 3 & - \\
Zerynthia polyxena ([Den. et Schiff.], 1775) & DF, GMF & 27.3 & 2 & - \\
Zygaena centaureae Fischer von Waldheim, 1832 & FM & 33.3 & 4 & - \\
\hline Hymenoptera & & & & \\
Bombus hypnorum (Linnaeus, 1758) & EMF & 85.7 & 3 & - \\
Bombus terrestris (Linnaeus, 1758) & GMF & 25.0 & 2 & - \\
Orussus abietinus (Scopoli, 1763) & GMF, MF, CF & 53.8 & 4 & - \\
Parnopes grandior (Pallas, 1771) & GMF, ECF & 30.8 & 4 & 3 \\
Xylocopa valga Gerstaecker, 1872 & GF, GCF, & 78.9 & 2 & - \\
\hline Diptera & & & & - \\
\hline
\end{tabular}

\section{Diptera}

Laphria gibbosa (Linnaeus, 1758)

\begin{tabular}{lcccc} 
Laphria gibbosa (Linnaeus, 1758) & CF, GMF, EMF & 57.1 & 2 & - \\
\hline Mollusca & & & & \\
Acroloxus lacustris (Linnaeus, 1758) & WBS & 14.3 & 4 & - \\
Planorbis carinatus O.F. Müller, 1774 & WBS & 50.0 & 4 & - \\
\hline Total & & & 121 & 12 \\
\hline
\end{tabular}

Abbreviations: BCF - Burned Coniferous Forest, CF - Coniferous Forest, DF - Deciduous Forest, MF - Mixed Forest, ECF - Edge of Coniferous Forest, EDF - Edge of Deciduous Forest, EMF Edge of Mixed Forest, GCF - Glade of Coniferous Forest, GDF - Glade of Deciduous Forest, GMF - Glade of Mixed Forest, FM - Floodplain Meadow, WBS - Water Body and Shore, MMH - ManMade Habitats, SM - Sphagnum Mire. 